Article

\title{
Performance Evaluation of the Physical and Combustion Properties of Briquettes Produced from Agro-Wastes and Wood Residues
}

\author{
Babajide Charles Falemara ${ }^{1, *(\mathbb{D})}$, Victoria Ibukun Joshua ${ }^{2}$, Oluwaseyi Oluwafunmi Aina ${ }^{1}$ and \\ Rivi David Nuhu ${ }^{3}$ \\ 1 Forestry Research Institute of Nigeria, P.M.B. 5054, Forest Hills, Jericho, Ibadan 200272, Oyo State, Nigeria; \\ seyifunmiaina@gmail.com \\ 2 Montane Forest Research Station, Jos 930222, Plateau State, Nigeria; vijoshua65@gmail.com \\ 3 Federal College of Forestry, Jos, P.M.B. 2019, Jos 930222, Plateau State, Nigeria; charles_jide@yahoo.com \\ * Correspondence: falemara.bc@frin.gov.ng or fbabajide@gmail.com; Tel.: +234-806-6714-571
}

Received: 5 July 2018; Accepted: 12 August 2018; Published: 15 August 2018

\begin{abstract}
This study investigated the physical and combustion properties of briquettes produced from agricultural wastes (groundnut shells and corn cobs), wood residues (Anogeissus leiocarpus), and mixture of the particles at 15\%, 20\%, and 25\% starch levels (binder). A $6 \times 3$ factorial experiments in a Completely Randomized Design (CRD) was adopted for the study. The briquettes produced were analyzed for density, volatile matter, ash content, fixed carbon, and specific heat of combustion. The result revealed that the density ranged from $0.44 \mathrm{~g} / \mathrm{cm}^{3}$ to $0.53 \mathrm{~g} / \mathrm{cm}^{3}$, while briquettes produced from groundnut shells had the highest $\left(0.53 \mathrm{~g} / \mathrm{cm}^{3}\right)$ significant mean density. Mean volatile matter and ash content of the briquettes ranged from $24.35 \%$ to $34.95 \%$ and $3.37 \%$ to $4.91 \%$. A. leiocarpus and corn cobs particles had the lowest and highest ash content, respectively. The briquette fixed carbon and specific heat of combustion ranged from $61.68 \%$ to $68.97 \%$ and $7362 \mathrm{kcal} / \mathrm{kg}$ to $8222 \mathrm{kcal} / \mathrm{kg}$, respectively. Briquette produced from A. leiocarpus particles had the highest specific heat of combustion. In general, briquettes produced from A. leiocarpus particles and mixture of groundnut shell and A. leiocarpus particles at $25 \%$ starch level had better quality in terms of density and combustion properties and thus are suitable as an environmentally friendly alternative energy source.
\end{abstract}

Keywords: biomass; briquette; combustion; density; energy source

\section{Introduction}

An estimated 3 billion people in our current estimated 7.63 billion people in the world [1,2] rely upon wood, kerosene, biomass, and coal for domestic cooking. This has led to rapid deforestation and loss of more than 3\% of the world's forests on an annual basis. The use of wood is increasing on daily basis especially in the less technologically developed countries of the world [3]. With deforestation becoming a major problem in many parts of the developing world, Nigeria in particular, there is increased scarcity of fuelwood for household cooking, leaving kerosene and gas as the major cooking fuels [4].

Environmental and ecological problems are the major issues of concern associated with exploitation of these fuels. Another major challenge with these fuels is their unsustainability and projected depletion over the years. The use of fuel wood in the large scale without replenishing poses serious environmental consequences in many countries. Population increase in countries like Nigeria places more demands on energy to light and heat homes, to cook food, to drive transport and communication devices, and provide power for industries [5]. This situation, therefore, calls for an 
alternative means of supplementing the acute demand of wood for fuel energy. One of such alternative mean is the use of biomass for briquette production through carbonized or uncarbonised densification and manufacture processes [6]. Biomass in the form of wood and agricultural wastes constitute one of the third largest alternative source of primary energy in the world aside from coal and oil [7].

The large quantities of agricultural residues produced in Nigeria can play a significant role in meeting her energy demand. However, the abundant quantities of agricultural wastes and forest residues are neither managed effectively, nor utilized efficiently in all developing countries. The common practice is to burn these residues or they are left to decompose [8]. This burning consequently contributes to atmospheric pollution, but more than that, the burning or decomposition is a waste of available energy [9]. Recycling of this biomass helps to ameliorate the accumulation of greenhouse gases [10] and can be renewably converted into liquid, solid, or gas states [11]. Briquetting provides a value addition to the sustainable and efficient utilization of the biomass residues [12].

The natural environment cannot continue to provide cooking fuel for the ever-increasing population. An alternative and sustainable fuel energy source becomes imperative. Considerable studies have been carried out on briquette production using wood and agricultural residues such groundnut shell [13], mixed sawdust of tropical wood species [14], water hyacinth-cow dung [4], melon shells [8], rice husk [15] maize cob [16], watermelon peels [17] among others. However, few studies have been reported on briquettes produced from blended wood particles and agro wastes. In addition, a simple low-cost briquette machine [18] was locally fabricated for the processing technology in this study, as the cost of modern processing technology is quite high and beyond the capability of rural/local entrepreneurial communities. This will enhance affordability, suitability to local condition [19], self-reliance, job and wealth creation, ease of acceptability, and adoption of the briquette as an alternative fuel wood.

This paper thus examined the physical and combustion properties of briquettes produced from wood residues (Anogeissus leiocarpus), agricultural wastes (groundnut shells and corn cobs), and mixture of the wood and agro wastes.

\section{Materials and Method}

\subsection{Study Site}

The experiment was carried out in Federal College of Forestry Jos, Plateau State, Nigeria. Jos, located in Northern Guinea savanna is situated between latitudes $8^{\circ}$ and $30^{\prime}$ and $10^{\circ} 10^{\prime} \mathrm{N}$ and longitude $8^{\circ} 20^{\prime}$ and $9^{\circ} 30^{\prime} \mathrm{E}$.

\subsection{Materials for the Briquette Production}

The materials used for the briquette production include agricultural wastes from groundnut shell and corn cobs; and sawdust of Anogeissus leiocarpus (Figure 1a). The choice of the agricultural wastes was based on the relative abundance of the groundnut and annual corn crops in the northern parts of the country. The A. leiocarpus was chosen also based on its relative abundance in the timber market as well as high wood species density.

\subsection{Sample Preparation Procedures}

Wood samples (planks) of A. leiocarpus species were obtained from the timber market, processed, and converted into sawdust using a circular saw machine. The agricultural wastes (groundnut shells and corn cobs) were sourced from surrounding farms and pulverized into small particles. The particles were pre-treated in hot water at $100{ }^{\circ} \mathrm{C}$ for $30 \mathrm{~min}$ to remove extractives that may inhibit the binding ability of the particles and cassava starch. They were thereafter sundried for seven days to reduce the moisture content (Figure 1a-c). The particles were sieved using $80 \mu \mathrm{m}$ wire mesh to reduce the particles size into fine particles [14].

The starch binder at different levels of $15 \%, 20 \%$, and $25 \%$ [20,21] was prepared with $250 \mathrm{~mL}$ boiled water, stirred, and mixed with measured (Figure 1d) grams of separate particles homogenously 
and heterogeneously (at a mixing proportion of 50:50). The blended mixed stock was poured into the fabricated briquette moulder (Figure 1e) and compressed using hydraulic jack (Figure 1f). The briquettes were then removed and air dried for 30 days. Proximate analysis was thereafter carried out for properties investigation.

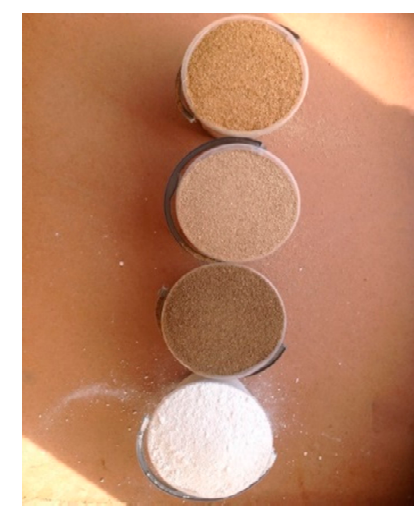

(a)

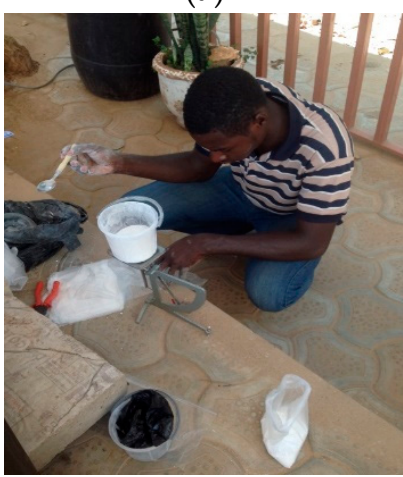

(d)

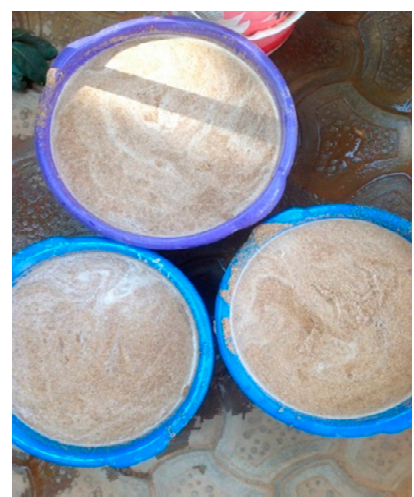

(b)

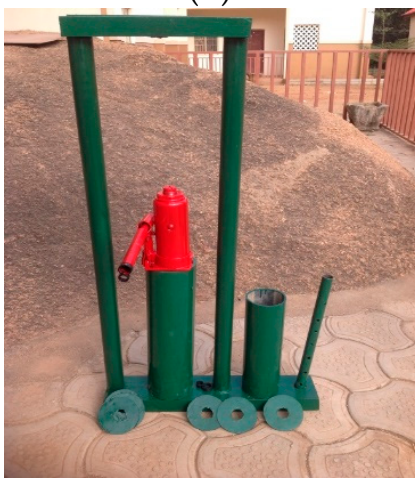

(e)

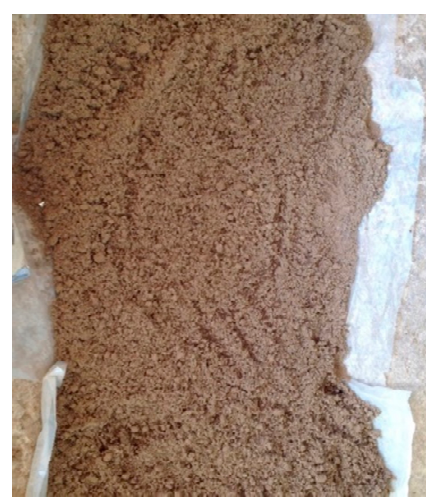

(c)

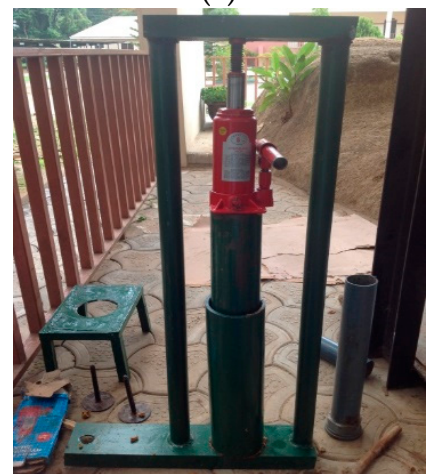

(f)

Figure 1. Materials used for the production of the briquette and production process. (a) Particle types and starch; (b) Pre-treatment in hot water $\left(100^{\circ} \mathrm{C}\right)$; (c) Drying of the particles; (d) Weighing of the materials (particle and starch); (e) Fabricated briquette hydraulic moulder; (f) Compression, hydraulic pressing, and moulding of the briquette.

\subsection{Experimental Design}

The experimental design for the study was $6 \times 3$ factorial experiments in a Completely Randomized Design (CRD). The factors consist of six (6) particle types (A. leiocarpus only (T1), groundnut shell only (T2), corn cobs only (T3), A. leiocarpus + Groundnut shell (T4), A. leiocarpus + Corn Cobs (T5), and A. leiocarpus + Groundnut shell + Corn Cobs (T6) and three starch levels $(15 \%, 20 \%$, and $25 \%$ starch levels)). This gave18 treatment combinations replicated four times (Figures 2a,b and 3a-f). 


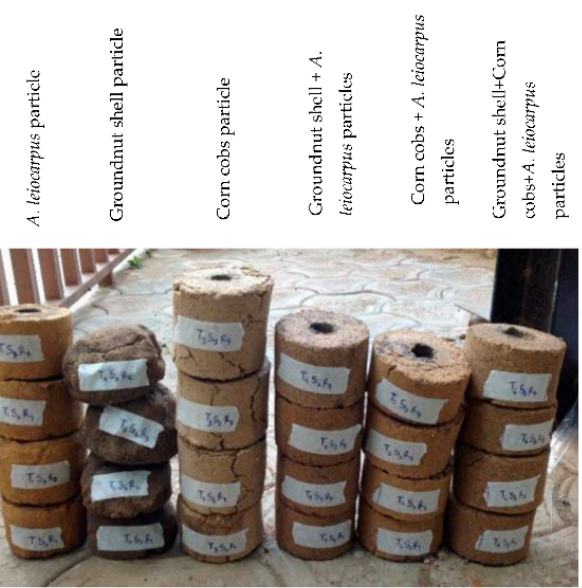

(a)
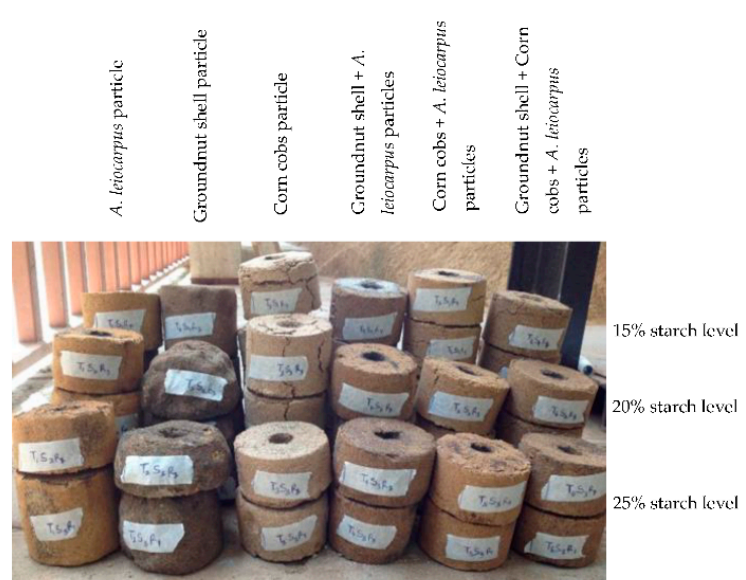

(b)

Figure 2. (a) Briquettes produced based on particle types; (b) Briquettes produced based on particle types and starch levels.

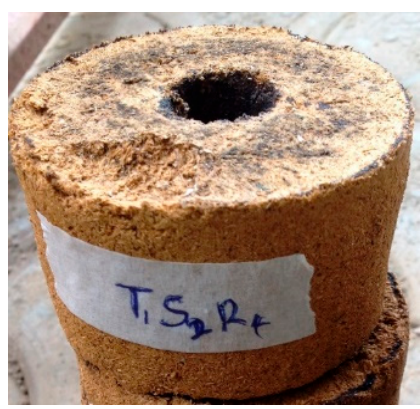

(a)

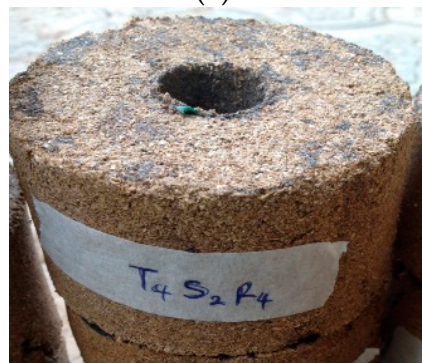

(d)

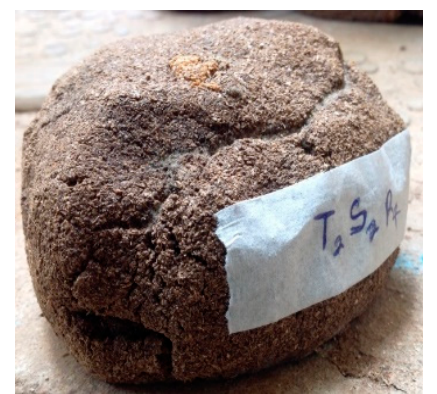

(b)

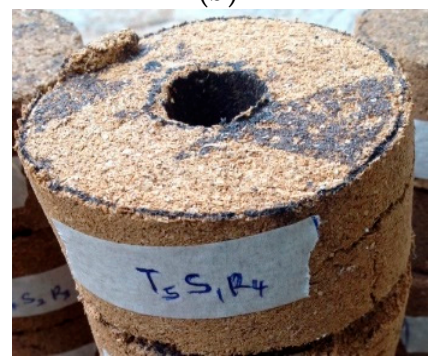

(e)

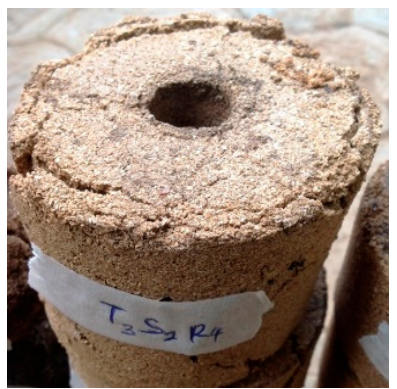

(c)

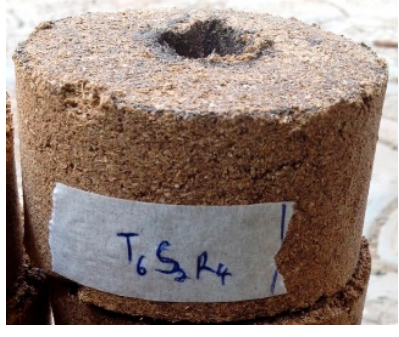

(f)

Figure 3. Briquettes produced from different particle types. (a) Anogeissus leiocarpus briquette (T1); (b) Groundnut Shell briquette (T2); (c) Corn Cobs briquette (T3); (d) Mixture of T1 + T2 briquette; (e) Mixture of $\mathrm{T} 1+\mathrm{T} 3$ briquette; (f) Mixture of $\mathrm{T} 1+\mathrm{T} 2+\mathrm{T} 3$ briquette.

\subsection{Variables Assessed}

The following parameters were determined on each of the sample briquettes [20,22].

- Relaxed density: The relaxed density refers to the density of the briquette measured after certain period of time. This was determined according to the weight and the volume $\left(\mathrm{V}=\pi \mathrm{r}^{2} \mathrm{~h}\right)$ of each briquette block based on its shape. The density of each briquette sample was calculated using the formula in Equation (1).

$$
\text { Density }\left(\frac{\mathrm{g}}{\mathrm{cm}^{3}}\right)=\frac{\text { Mass }(\mathrm{g})}{\text { Volume }(\mathrm{cm})^{3}}
$$

- Volatile matter $(\% V m)$ : The percentage volatile matter was determined by placing the crucible containing the oven dry weight (w2) in the furnace for $10 \mathrm{~min}$ at $550{ }^{\circ} \mathrm{C}$ to obtain weight (w3) after 
the escape of its volatile matter. The percentage volatile matter $(\% V m)$ was calculated using the formula as shown in Equation (2);

$$
\begin{aligned}
& \text { Volatile matter }(\%) \\
& =\frac{\left(\text { Dry weight }(w 2)-\text { weight of sample }(w 3) \text { after } 10 \text { min. in the furnace at } 500{ }^{\circ} \mathrm{C}\right)}{\text { Oven dry weight }(w 2)}
\end{aligned}
$$

- Ash content (\%Ash): $2 \mathrm{~g}$ of oven dried pulverized briquette was placed in a crucible $(w 2)$. The crucible was then placed in the furnace for $4 \mathrm{~h}$ at $550{ }^{\circ} \mathrm{C}$ to obtain the ash weight $(w 4)$. Percentage ash content was calculated using Equation (3).

$$
\text { Ash Content }(\%)=\frac{\text { weight of Ash }(w 4)}{\text { Dry weight }(w 2)}
$$

- Fixed carbon $(\% F C)$ : The percentage fixed carbon was calculated by subtracting the sum of percentage volatile matter and percentage ash content from $100 \%$ Equation (4).

$$
\text { Fixed Carbon }(\%)=100 \%-(\% V m+\% \text { Ash })
$$

- Specific Heat of Combustion $(H c)$ : The specific heat of combustion $(H c)$ was calculated from the formula as shown in Equation (5);

$$
\text { Specific Heat of Combustion }(H c)=0.35(147.6 \times \% F C)+(144 \times \% V M)+(\% A s h)
$$

\subsection{Statistical Analysis}

Analysis of variance (ANOVA) resulting from 18 treatment combinations and four replicates was carried out to evaluate the performance of each of the treatments. Where significant differences existed, Duncan's Multiple Range Test (DRMT) was used for mean separation to determine the magnitude of differences.

\section{Results}

\subsection{Effect of Treatments and Starch Levels on Relaxed Density of the Briquette}

The relaxed density of the briquettes ranged between $0.46 \mathrm{~g} / \mathrm{cm}^{3}$ and $0.53 \mathrm{~g} / \mathrm{cm}^{3}$ (Figure 4) Briquette made with groundnut shell particles had the highest relaxed density $\left(0.53 \mathrm{~g} / \mathrm{cm}^{3}\right)$, while briquette produced with the three combinations of A. leiocarpus, groundnut shell, and corn cobs particles had the lowest $\left(0.46 \mathrm{~g} / \mathrm{cm}^{3}\right)$ relaxed briquette density. The statistical analysis revealed that groundnut shell had significantly higher effect on the relaxed density of the briquette, while the other particle treatments and treatment combinations were not significantly different from each other $(p \geq 0.05)$.

The effect of starch levels on briquette relaxed density (Figure 5) indicated that briquettes produced at $20 \%$ starch level had the highest relaxed density $\left(0.49 \mathrm{~g} / \mathrm{cm}^{3}\right)$, while briquette produced at the lowest starch level $(15 \%)$ had the lowest density $\left(0.46 \mathrm{~g} / \mathrm{cm}^{3}\right)$. The effects of the three starch levels on briquette relaxed density were not significantly different $(p \geq 0.05)$ from each other. 


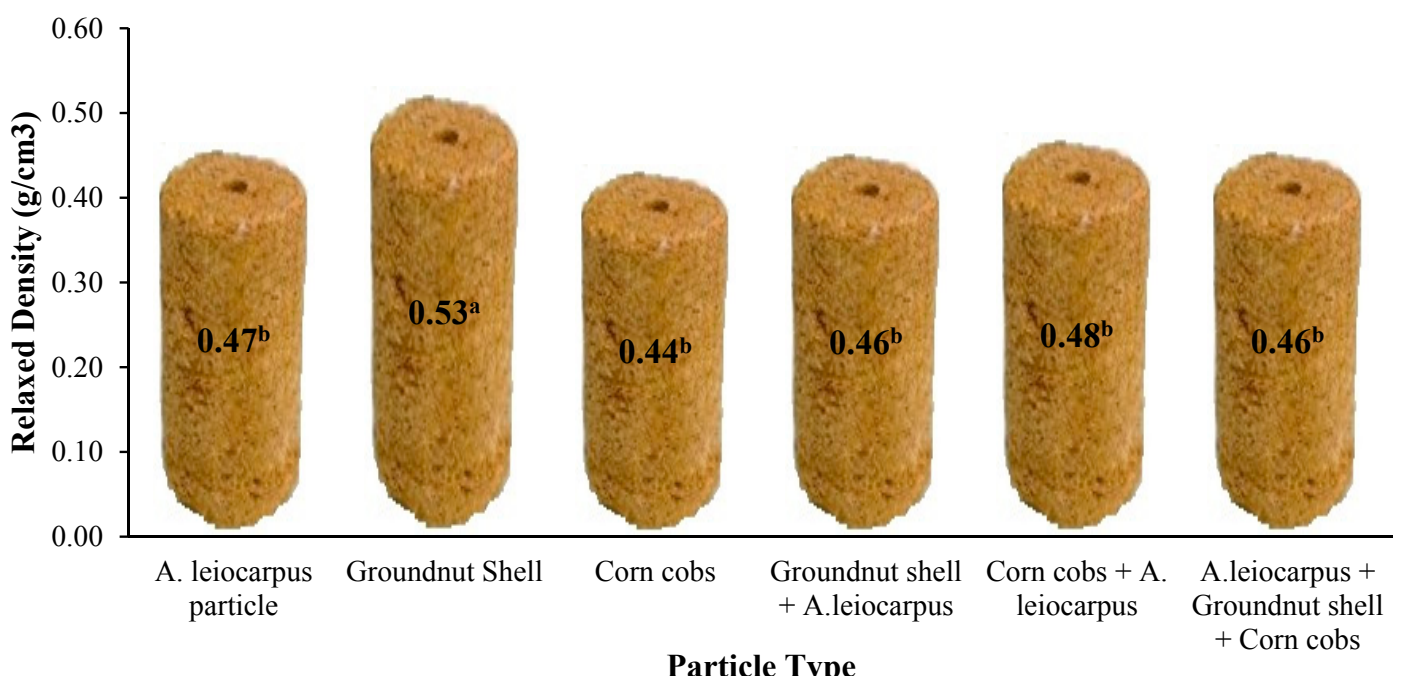

Figure 4. Mean effect of treatments on density $\left(\mathrm{g} / \mathrm{cm}^{3}\right)$ of briquette. Means in the same bar having the same superscript are not significantly different $(p \geq 0.05)$.

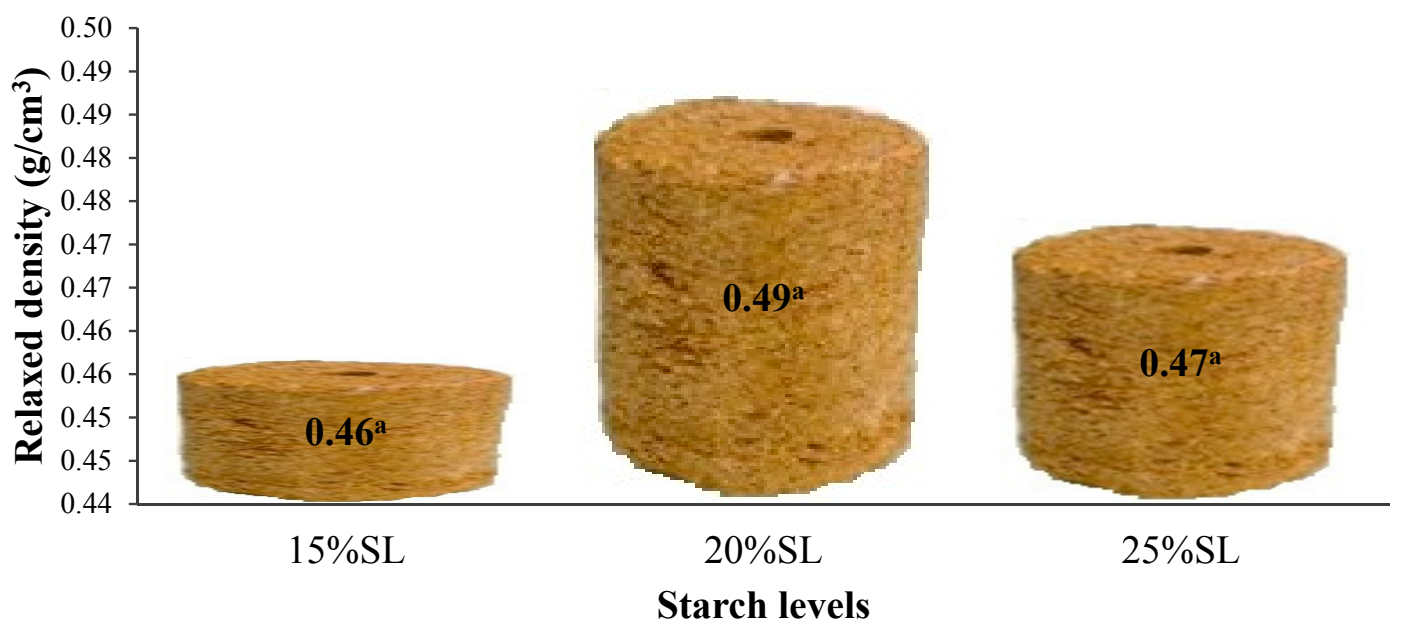

Figure 5. Mean effect of treatments on density $\left(\mathrm{g} / \mathrm{cm}^{3}\right)$ of briquette. Means in the same bar having the same superscript are not significantly different $(p \geq 0.05)$.

\subsection{Effect of Particle Types on Combustion Properties of the Briquettes}

The volatile matter (Figure 6) ranged between $26.4 \%$ and $34.9 \%$. Briquettes made with A. leiocarpus and mixture of groundnut shell and A. leiocarpus had the highest (34.9\%) and lowest (26.4\%) volatile matter, respectively. The statistical analysis revealed that the effects of all particle types excluding $A$. leiocarpus wood particle on volatile matter were not significantly different $(p \geq 0.05)$ from each other. The volatile matter of briquettes produced from the mixture of agricultural residues (A+gnut shell (26.4), A+corn cobs (28.5\%) and $\mathrm{A}+\mathrm{G}+\mathrm{C}(28.4 \%))$ and wood particle were lower than briquettes produced from homogenous particle types (A. leiocarpus (34.9\%), groundnut shell (29.8\%) and corn cobs (31.2\%)). Ash content (Figure 3) of the briquettes ranged between $3.4 \%$ and $4.9 \%$. The ash content of the briquettes was not significantly different from each other, although corn cob briquette had the highest ash content $(4.9 \%)$, while briquette from A. leiocarpus particle had the lowest ash content (3.4\%). The mixture of agricultural residues (groundnut shell and corn cobs) and wood particles had the same ash content.

The specific heat of combustion and fixed carbon of the briquettes ranged from $7362 \mathrm{kcal} / \mathrm{kg}$ to $8222 \mathrm{kcal} / \mathrm{kg}$ and 61.7 to $69 \%$, respectively (Figure 7). As similarly observed for volatile matter, the specific heat of combustion of the briquettes produced from mixed particles (groundnut shell 
and A. leiocarpus (7362 kcal/ kg); corn cobs and A. leiocarpus (7561 kcal/kg), A. leiocarpus, groundnut shell, and corn cobs $(7589 \mathrm{kcal} / \mathrm{kg}))$ were lower than the specific heat of combustion of briquettes produced from homogenous A. leiocarpus (8222 kcal/ $\mathrm{kg}$ ), groundnut shell $(7677 \mathrm{kcal} / \mathrm{kg}$ ), and corn cobs $(7882 \mathrm{kcal} / \mathrm{kg})$ particles. On the other hand, the fixed carbon of briquettes produced from mixed particles (groundnut shell and A. leiocarpus (69\%); corn cobs and A. leiocarpus (66.8\%), A. leiocarpus, groundnut shell and corn cobs $(67.7 \%))$ were higher than the fixed carbon of unmixed particle types (A. leiocarpus $(61.7 \%)$, groundnut shell $(65.4 \%)$ and corn cobs $(63 \%)$ particles). Briquette produced from mixture of groundnut shell and A. leiocarpus particles had the lowest specific heat of combustion $(7362 \mathrm{kcal} / \mathrm{kg}$ ) and highest fixed carbon content $(69 \%)$. The specific heat of combustion and fixed carbon were not significantly different from each other $(p \geq 0.05)$.

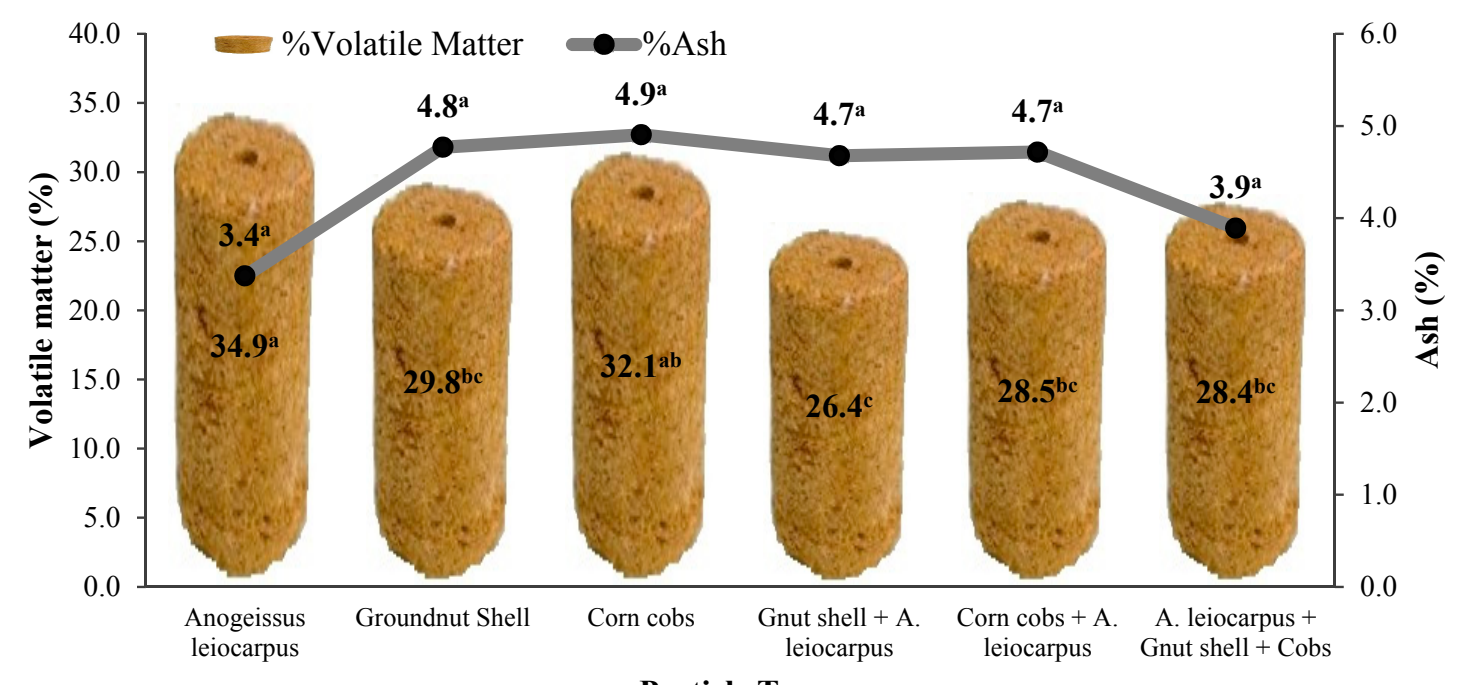

Particle Types

Figure 6. Effect of particle types on percentage volatile matter (\%VM) and ash content $(\%)$ of the briquette. Means in the same bar having the same superscript are not significantly different $(p \geq 0.05)$.

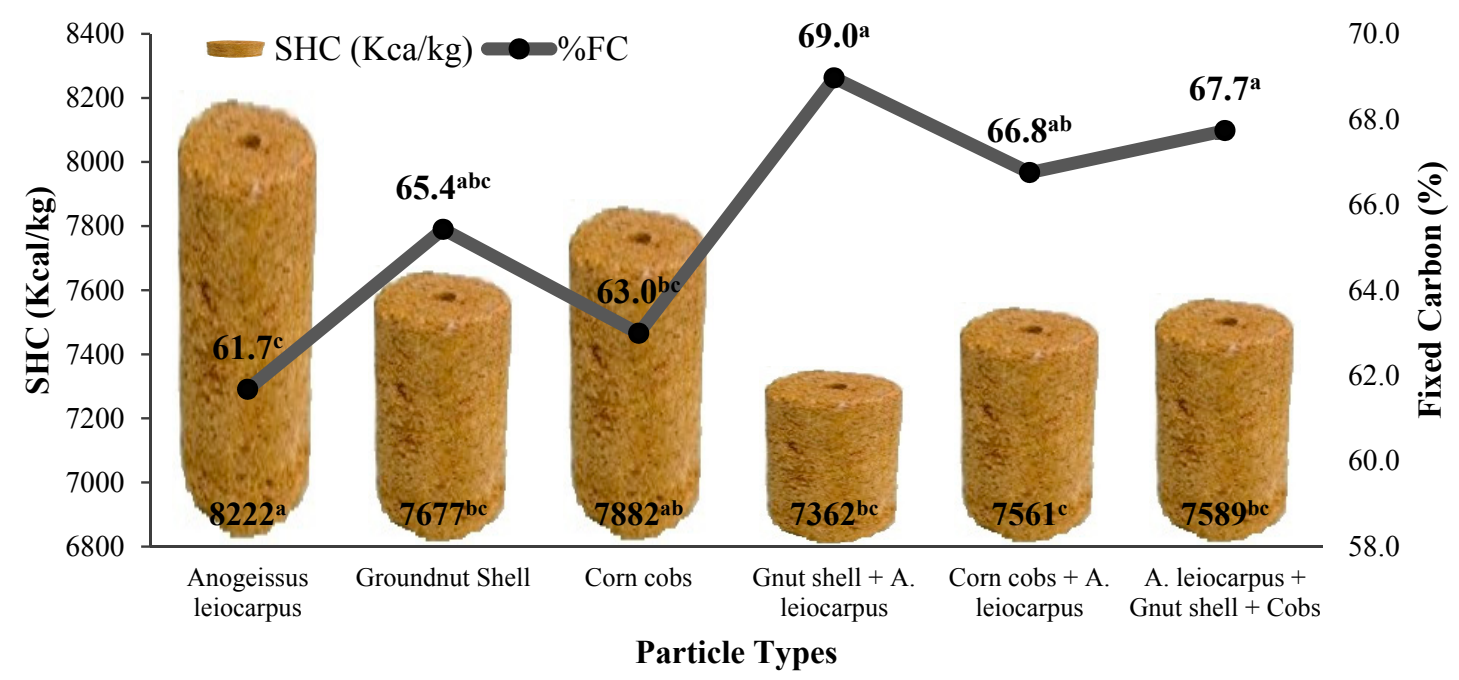

Figure 7. Effect of particle types on specific heat of combustion (SHC) and fixed carbon (\%FC) of the briquette. Means in the same bar having the same superscript are not significantly different $(p \geq 0.05)$. 


\subsection{Effect of Starch Levels on Combustion Properties of the Briquettes}

The result of findings as shown in Figures 8 and 9 revealed that briquettes produced at $20 \%$ starch level had the lowest volatile matter $(24.2 \%)$ and specific heat of combustion $(7165 \mathrm{kcal} / \mathrm{kg})$, while $25 \%$ starch level produced briquettes with the highest volatile matter $(33.5 \%)$ and specific heat of combustion $(8051 \mathrm{kcal} / \mathrm{kg})$. On the other hand, briquettes produced at $20 \%$ starch level had the highest ash content $(4.7 \%)$ and fixed carbon $(71.1 \%)$, while $25 \%$ starch level produced briquettes having the lowest ash content $(4.1 \%)$ and fixed carbon $(62.4 \%)$. In addition, the volatile matter of briquettes produced at $15 \%$ and $25 \%$ starch levels were not significantly different from each other as similarly observed for specific heat of combustion and fixed carbon. The effects of the three starch levels $(15 \%, 20 \%$ and $25 \%)$ on ash content of the briquettes were not significantly different from each other $(p \geq 0.05)$. The effects of $20 \%$ starch level on fixed carbon and specific heat of combustion were significantly $(p \leq 0.05)$ higher and lower respectively from the other starch levels (15\% and $25 \%)$.

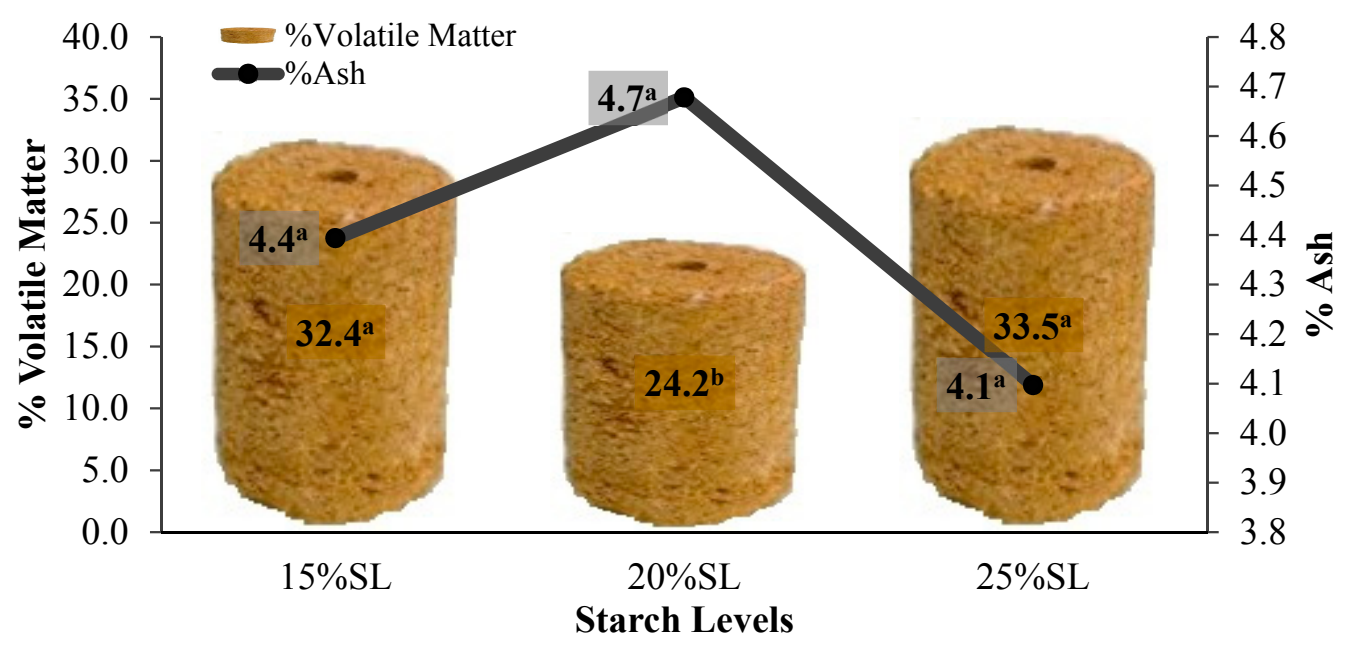

Figure 8. Effect of starch levels on percentage volatile matter (\%VM) and Ash (\%) of the briquette. Means in the same bar having the same superscript are not significantly different $(p \geq 0.05)$.

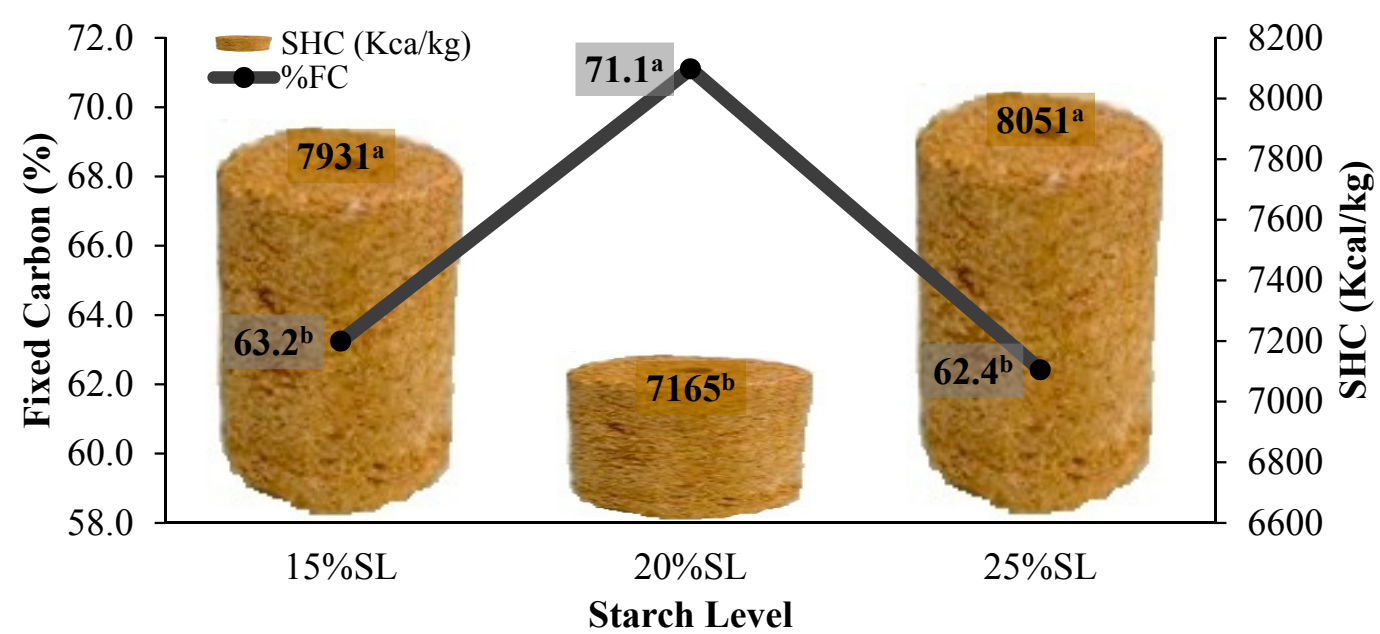

Figure 9. Effect of starch levels on percentage specific heat of combustion (kcal/ $\mathrm{kg}$ ) and fixed carbon $(\% F C)$ of the briquette. Means in the same bar having the same superscript are not significantly different $(p \geq 0.05)$. 


\section{Discussion}

\subsection{Relaxed Density}

The briquette produced from groundnut shell had poor compaction and agglomeration at higher starch level which contributed to its higher significant effect on density (Figures 4 and 5). This assertion contradicts the report of Egbewole et al. [20] on poor agglomeration of briquette at lower starch levels of $10 \%$ and $15 \%$ for wood sawdust. The implication of this is that particle sizes and types have great influence on density of briquettes as similarly observed by Aina et al. [23]. Quality of the mixture composition and technological characteristics of the bio-raw material have important influence on particle agglomeration during the pressing process [24]. In collaboration with the findings of Tembe et al. [21] on comparative analysis of combustion properties of briquettes from groundnut shell and rice husk, the starch level had no significant effect on the briquette density. The relaxed density obtained in the study is within the range of values as obtained by Ige et al. [17] and Onuegbu et al. [25] who reported a relaxed density ranging between $0.319 \mathrm{~g} / \mathrm{cm}^{3}$ and $0.590 \mathrm{~g} / \mathrm{cm}^{3}$. In addition, high density is an indication of longer burning time, as such briquettes produced from groundnut shell $\left(0.53 \mathrm{~g} / \mathrm{cm}^{3}\right)$, the mixture of corn cobs and A. leiocarpus $\left(0.48 \mathrm{~g} / \mathrm{cm}^{3}\right)$, and A. leoicarpus $\left(0.47 \mathrm{~g} / \mathrm{cm}^{3}\right)$ particles will tend to burn for a longer time compare to others.

\subsection{Volatile Matter}

The range of values for volatile matter $(24.2 \%$ and $34.95 \%)$ of briquettes produced in this study (Figures 6 and 8 ) is lower than range of $43 \%$ to $49 \%$ obtained by Adegoke et al. [14] for briquettes produced from mixed sawdust of tropical hardwood species, $72.33 \%$ to $77.44 \%$ for briquettes produced from three hardwood species [26], and 68\% stated by Ige et al. [17]. Adetogun et al. [16] in their study on briquettes from maize cobs reported a higher volatile matter ranging between $57.82 \%$ and $62.91 \%$ compared to a lower value of $31.2 \%$ and $33.5 \%$ for briquettes made from maize cob in this present study (Figures 6 and 8). Conversely, Egbewole et al. [20] and Sotannde et al. [27] reported a lower volatile matter for briquettes made from wood sawdust (13.89\% to $19.33 \%)$ and neem-wood residues (10 to $13 \%$ ), respectively.

Volatile matter is a mixture of short- and long-chain hydrocarbons such as combustible or incombustible gases or combination of both released during burning. These gases strongly affect the combustion behavior of briquettes [28]. Lower volatile matter is an indication that the briquettes might not be easy to ignite, but once ignited they will burn smoothly, while high volatile matter results in high combustibility at low ash content [29]. It was observed that briquettes with higher volatile matter (Figure 6) had higher specific heat of combustion and lower fixed carbon (Figure 7). The higher value of the volatile content in briquettes produced from homogenous particles (A. leiocarpus, groundnut shell, corn cobs) decreased and increased the specific heat of combustion and fixed carbon respectively of briquettes produced from the heterogeneous/mixed particles (wood and agro wastes). In similar consonance, the mixture of wood and agro residues produced briquettes of lower volatile matter and specific heat of combustion, thus requiring lower amount of heat energy to dissipate the combustible and incombustible gases in the briquettes before ignition can occur as similarly observed by Onukak et al. [30]. As such, blending of higher volatile material (wood residues) with lower volatile material (agro wastes) resulted in the production of optimum quality briquette. In contrast, the higher the volatile matter of a briquettes, the higher the amount of emissions during burning. This implies that low volatile matter is required for good quality briquette.

\subsection{Ash Content}

The low ash content as observed in this study (Figures 6 and 8) is a reflection of the high specific heat of combustion/heating value (Figures 7 and 9) which is an indication that the briquette does not contain high mineral (non-combustible) matters. As posited by Sotannde et al. [27], ash content normally causes an increase in the combustion remnant, thereby lowering the heating effect. The briquettes produced at $25 \%$ 
starch level had the lowest ash content (Figure 8), thus indicating its suitability in briquette production. The low ash content as observed in this study corroborates the findings of Akowuah et al. [31], Adetogun et al. [16], and Sotannde et al. [27] who all reported a lower ash content of $2.6 \%, 1.06 \%$ to $1.23 \%$ and 3.50\% to $5.75 \%$ respectively. On the contrary, higher ash content ranging from $19.07 \%$ to $21.72 \%, 10.44 \%$ to $42.33 \%$, $18.67 \%$ to $22.06 \%$, and $18 \%$ were reported by Emerhi [26], Ogbuagu et al. [15], Ikelle and Anyigor [32], and Ige et al. [17], respectively. This contradiction can be explained by the fact that the corn cob and groundnut shell briquettes produced in this study had higher ash content ( $4.8 \%$ to $4.9 \%)$, but the mixture of wood residue (A. leiocarpus) of lower ash content to the agro wastes considerably reduced their ash contents (Figure 6) and thus reducing the amount of heating value required for combustion processes (Figure 7). Lower ash content is an indication of good quality briquette, as the ash content of briquettes produced in this study is around the acceptable $4 \%$ tolerance level of ash content for fuel [33]. Higher ash content in a fuel usually leads to higher dust emissions, air pollution, and affects the combustion volume and efficiency of combustion [34].

\subsection{Specific Heat of Combustion}

Briquette produced from the wood residue (A. leiocarpus) had higher specific heat of combustion than those produced from the agro wastes (groundnut shell and corn cob). This might be attributed to the wood density of the A. leiocarpus species, which is higher than groundnut shell and corn cob. The specific heat of combustion values ranging between $7362 \mathrm{kcal} / \mathrm{kg}$ and $8222 \mathrm{kcal} / \mathrm{kg}$ (Figures 7 and 9) as obtained in this study is within the range of values $(4937 \mathrm{kcal} / \mathrm{kg}-12,665.67 \mathrm{kcal} / \mathrm{kg})$ reported by Aina et al. [23]. However, Egbewole et al. [20] and Tembe et al. [21] reported a lower specific heat of combustion ranging from $4908.52 \mathrm{kcal} / \mathrm{kg}$ to $5257.66 \mathrm{kcal} / \mathrm{kg}$ and $3284 \mathrm{kcal} / \mathrm{kg}$ to $3980 \mathrm{kcal} / \mathrm{kg}$, respectively.

\subsection{Fixed Carbon}

Fixed carbon gives an indication of the proportion of char that remains after volatile matter is distilled off. It gives a rough estimate of the heating value of a fuel and acts as the main heat generator during burning [31]. The fixed carbon content of briquettes produced (Figures 7 and 9) is close to the high values obtained by Sotannde et al. [27] and Egbewole et al. [20] ranging between $85.25 \%$ and $85.95 \%$. According to Sotannde et al. [27], it is expected that the high fixed carbon and its smokeless flame will enhance the heat value and combustion duration of briquette. However, the fixed carbon as reported in this study is relatively higher than $9.06 \%$ to $11.46 \%$ obtained by Adegoke et al. [14] $5.75 \%$ to $8.28 \%$ stated by Emerhi [26], $16.80-20.90 \%$ quantified by Adetogun et al. [16], and $15 \%$ fixed carbon estimated by Ige et al. [17] who all worked on briquettes produced from homogenous particles. A good quality and efficient fuel briquette is dependent on lower volatile matter and ash content with a higher fixed carbon content [35] in collaboration with result of findings of this study.

The percentage of fixed carbon content in briquettes is a critical factor that influences the calorific value of fuel [36]. As the percentage fixed carbon of the homogenous particle briquettes (A. leiocarpus, ground shell, corn cobs) is less than that of the heterogeneously mixed wood and agro wastes briquettes, the specific heat of combustion value is more than that of the heterogeneously mixed wood and agro wastes briquettes. This is contrary to the assertion of Onukak et al. [30] who posited that high fixed carbon implies high calorific value. The variance to this observation might be attributed to the blending of the wood residue to the agro wastes with varying inherent volatile matter, which primarily explains the reason for lower ash content and lower specific heat of combustion.

The observed trend of decrease in specific heat of combustion and increase in fixed carbon at $20 \%$ starch level might be attributed to increasing binder concentration [30] from $10 \%$ to $20 \%$. Although a sharp decrease in fixed carbon and increase in specific heat of combustion was observed beyond $30 \%$ starch level. This might be related to the fact that the optimum and suitable starch binder level for quality briquettes stands below $30 \%$. According to Zubairu and Gana [37], fixed carbon of briquettes made from agro waste increased with increasing binder concentration, while Wang et al. [38] attributed the occurrence to probable loss of moisture during the overall briquetting process, which will also result in higher fixed carbon. 


\section{Conclusions}

The study examined the physical and combustion properties of briquettes produced from wood residues (Anogeissus leiocarpus) and agricultural wastes (groundnut shells and corn cobs) as well as heterogeneous combination of the particles. The study affirmed that briquettes produced from A. leiocarpus particles and mixture of groundnut shell and A. leiocarpus particles produced at $25 \%$ starch level had better quality in terms of density, agglomeration, compaction, and combustion properties with respect to high volatile matter, low ash content, high fixed carbon, and high specific heat of combustion. There were little variations in the quality of the briquette produced from these two particle types compared to other homogeneous and heterogeneous particle types. This study has been able to confirm that agricultural wastes alongside wood waste can be utilized in producing quality briquettes. As such, wood wastes from A. leiocarpus and a combination of groundnut shell and A. leiocarpus particle type using $25 \%$ starch level are suitable for briquette production due to better combustion performance.

Subsequently, the briquettes will provide better and efficient environmentally friendly alternatives to other forms of energy source, help to solve agricultural and wood wastes management issues, and help in the restoration of already destroyed forests by proving alternative fuel wood. It could also enhance market diversification, rural economic empowerment, and job opportunities.

Author Contributions: B.C.F. conceived the research idea, adopted and designed the fabricated briquette moulder, wrote the original draft manuscript, analyzed the data, reviewed and edited the manuscript. V.I.J. participated in the investigation and production process, reviewed and edited the manuscript. O.O.A. conducted the laboratory analysis and contributed to manuscript preparation and review. R.D.N. sourced and fabricated the materials used for the methodology, participated in the investigation and production process, and contributed to the manuscript preparation.

Funding: This research received no external funding.

Conflicts of Interest: The authors declare no conflicts of interest.

\section{References}

1. World Health Organization. Household Air Pollution and Health. Fact Sheet 2018. Available online: http:/ / www.who.int/news-room/fact-sheets/detail/household-air-pollution-and-health (accessed on 4 July 2018).

2. Worldometers. Current World Population. Available online: Http://www.worldometers.info/worldpopulation/? (accessed on 4 July 2018).

3. Aremu, M.O.; Agarry, S.E. Enhanced biogas production from poultry droppings using corn cob and waste paper as co-substrates. Int. J. Eng. Sci. Technol. 2013, 5, 247-253.

4. Frank, O.O.; Akhihiero, T.E. Fuel briquettes from water hyacinth-cow dung mixture as alternative energy for domestic and agro-industrial applications. J. Energy Technol. Policy 2011, 3, 56-61.

5. Ismaila, A.; Zakari, I.Y.; Nasiru, R.; Tijjani, B.I.; Abdullahi, I.; Garba, N.N. Investigation on biomass briquettes as energy source in relation to their calorific values and measurement of their total carbon and elemental contents for efficient biofuel utilization. Adv. Appl. Sci. Res. 2013, 4, 303-309.

6. International Tropical Timber Organization. Tropical Forest Update, 15, 1, 2005; International Tropical Timber Organization (ITTO): Yokohama, Japan, 2005; p. 32.

7. Chen, L.; Xing, L.; Han, L. Renewable energy from agro-residues in China: Solid biofuels and biomass briquetting technology. Renew. Sustain. Energy Rev. 2009, 13, 2689-2695. [CrossRef]

8. Oladeji, J.T. Utilization of Potential of Melon Shells for Pyrolysis as Biomass Fuels. World Rural Obs. 2012, 4, 60-64.

9. Oladeji, J.T.; Ogunsola, A.D. Pyrolysis of Sawdust into Medium-Grade Fuels and Chemical Preservatives. In Proceedings of the 2nd Engineering Conference of the School of Engineering, Federal Polytechnic, Offa, Nigeria, 13-15 July 2010; pp. 64-67.

10. Havrland, B.; Ivanova, T.; Łapczyńska-Kordon, B.; Kolarikova, M. Comparative analysis of bio-raw materials and biofuels. In Proceedings of the 12th International Scientific Conference on Engineering for Rural Development, Jelgava, Latvia, 23-24 May 2013; pp. 541-544. 
11. Kambo, H.S.; Dutta, A. A comparative review of biochar and hydrochar in terms of production, physical-chemical properties and applications. Renew. Sustain. Energy Rev. 2015, 45, 359-378. [CrossRef]

12. Li, Y.; Liu, H. High-pressure densification of wood residues to form an upgraded fuel. Biomass Bioenergy 2018, 19, 177-186. [CrossRef]

13. Musa, N.A. Comparative fuel characterization of rice husk and groundnut shell briquettes. NJREDI 2007, 6, 23-27.

14. Adegoke, I.A.; Baiyewu, R.A.; Aina, K.S.; Adesope, A.S.; Adejoba, A.L.; Abah, G.B. Combustion properties of briquette produced from mixed sawdust of tropical wood species. Climate Change and Forest Resources Management: The Way Forward. In Proceedings of the 2nd Biennial National Conference of the Forests and Forest Products Society, Akure, Nigeria, 16-18 April 2010; pp. 368-371.

15. Ogbuagu, J.; Onuegbu, T.; Ikelle, I.I.; Chimezie, O.; Anyigor, C. Production and analysis of the heating properties of coal and Rice husk briquettes using $\mathrm{CaSO}_{4}$ as a binder. J. Phys. Sci. Innov. 2013, 1, 35-44.

16. Adetogun, A.C.; Ogunjobi, K.M.; Are, D.B. Combustion properties of briquettes produced from maize cob of different particle sizes. J. Res. Forest. Wildl. Environ. 2014, 6, 28-38.

17. Ige, A.R.; Elinge, C.M.; Hassan, L.G.; Adegoke, I.A.; Ogala, H. Effect of binder on physicochemical properties of fuel briquettes produced from watermelon peels. AASCIT J. Energy 2018, 5, 23-27.

18. Somsuk, N.; Srithongkul, K.; Wessapan, T.; Teekasap, S. Design and Fabricate a Low Cost Charcoal Briquette Machine for the Small and Micro Community Enterprises. In Proceedings of the 1st International Conference of the Council of Deans of Architecture School Thailand (CDAST 2008), Phitsanulok, Thailand, 23-25 May 2008; p. 7.

19. Obi, O.F.; Akubuo, C.O.; Okonkwo, W.I. Development of an appropriate briquetting machine for use in rural communities. Int. J. Eng. Adv. Technol. 2013, 2, 578-582.

20. Egbewole, Z.T.; Alao, J.S.; Ogunsanwo, O.Y.; Sotunde, O.A.; Aina, K.S.; Akinyemi, O. Potential use of wood production. Altern. Energy Gener. J. 2009, 5, 181-195.

21. Tembe, E.T.; Adeogun, A.C.; Elaigwu, V.O. Comparative Analysis of Combustion Properties of Briquettes from Groundnut shell and rice husk. In Proceedings of the 36th Annual Conference of the Forestry Association of Nigeria, Edo State, Nigeria, 5-10 December 2011; pp. 389-394.

22. Fuwape, J.A.; Sobanke, A.O. Combustion characteristics of wood briquettes produced from sawdust. In Proceedings of the National Conference of Nigerian Society of Agricultural Engineering, Kano, Nigeria, 8-11 September 1998.

23. Aina, K.S.; Baiyewu, R.A.; Ogunleye, M.B.; Adegoke, I.A.; Adesope, A.S.; Fatade, B.O. Evaluation of Combustion properties of briquette produced from Cedrella odorata, Terminalia superba and Cordia millenii. In Proceedings of the 2nd Biennial National Conference of Forests and Forest Products Society, Akure, Nigeria, 26-29 April 2010; pp. 395-400.

24. Muntean, A.; Ivanova, T.; Havrland, B.; Pobedinsky, P.; Vrancean, V. Particularities of bio-raw material particle agglomeration during solid fuel pressing process. In Proceedings of the 12th International Scientific Conference on Engineering for Rural Development-Proceedings, Latvia University of Agriculture Faculty of Engineering, Jelgava, Latvia, 23-24 May 2013; pp. 505-509.

25. Onuegbu, T.U. Improving Fuel wood Efficiency in Rural Nigeria: A case for Briquette Technology. Natl. Mag. Chem. Soc. Niger. 2010, 5, 35-39.

26. Emerhi, E.A. Physical and combustion properties of briquettes produced from sawdust of three hardwood species and different organic binders. Adv. Appl. Sci. Res. 2011, 2, 236-246.

27. Sotannde, O.A.; Oluyege, A.O.; Abah, G.B. Physical and combustion properties of charcoal briquettes from neem wood residues. Int. Agrophys. 2010, 24, 189-194.

28. Shukla, S.; Vyas, S. Study of Biomass Bio pellets, Factors Affecting Its Performance and Technologies Based on Bio pellets. IOSR J. Environ. Sci. Toxicol. Food Technol. 2015, 9, 37-44.

29. Maninder, R.; Singh, K.; Grover, S. Using agricultural residues as a Biomass Briquetting: An Alternative source of energy. J. Electr. Electron. Eng. 2012, 1, 11-15.

30. Onukak, I.E.; Mohammed-Dabo, I.A.; Ameh, A.O.; Okoduwa, S.I.R.; Fasanya, O.O. Production and Characterization of Biomass Briquettes from Tannery Solid Waste. Recycling 2017, 2, 17. [CrossRef]

31. Akowuah, O.J.; Kermausuor, F.; Mitchual, J.S. Physicochemical characteristics and market potential of sawdust charcoal briquette. Int. J. Energy Environ. Eng. 2012, 3, 18-26. [CrossRef] 
32. Ikelle, I.I.; Anyigor, C. Comparative Thermal Analysis of the Properties of Coal and Corn Cob Briquettes. IOSR J. Appl. Chem. 2014, 7, 93-97. [CrossRef]

33. Grover, P.D. Biomass briquetting: Technical and feasibility analysis under biomass densification research project (Phase II). In Proceedings of the International Workshop on Biomass Briquetting, New Delhi, India, 3-6 April 1995; Grover, P.D., Mishra, S.K., Eds.; FAO Regional Wood Energy Development Programme in Asia: Bangkok, Thailand, 1995; p. 193.

34. Katimbo, A.; Nicholas, K.; Simon, K.; Hussein, B.K.; Peter, T. Potential of densification of mango waste and effect of binders on produced briquettes. Agric. Eng. Intl. J. 2014, 16, 146-155.

35. Asamoah, B.; Nikiema, J.; Gebrezgabher, S.; Odonkor, E.; Njenga, M. A Review on Production, Marketing and Use of Fuel Briquettes; Resource Recovery and Reuse Series 7; International Water Management Institute (IWMI), CGIAR Research Program on Water, Land and Ecosystems (WLE): Colombo, Sri Lanka, 2016; p. 51.

36. Thabuot, M.; Pagketanang, T.; Panyacharoen, K.; Mongkuta, P.; Wongwicha, P. Effect of applied pressure and binder proportion on the fuel properties of holey bio-briquettes. Energy Procedia. 2015, 79, 890-895. [CrossRef]

37. Zubairu, A.; Gana, S.A. Production and characterization of briquette charcoal by carbonization of agro-waste. Energy Power 2014, 4, 41-47.

38. Wang, Q.; Han, K.; Gao, J.; Li, H.; Lu, C. The pyrolysis of biomass briquettes: Effect of pyrolysis temperature and phosphorus additives on the quality and combustion of bio-char briquettes. Fuel 2017, 199, 488-496. [CrossRef]

(C) 2018 by the authors. Licensee MDPI, Basel, Switzerland. This article is an open access article distributed under the terms and conditions of the Creative Commons Attribution (CC BY) license (http:/ / creativecommons.org/licenses/by/4.0/). 